\title{
Author Correction: Prolonged activation of innate immune pathways by a polyvalent STING agonist
}

Suxin Li, Min Luo, Zhaohui Wang, Qiang Feng, Jonathan Wilhelm (D), Xu Wang, Wei Li, Jian Wang, Agnieszka Cholka, Yang-xin Fu, Baran D. Sumer (D), Hongtao Yu (D) and Jinming Gao (D)

Correction to: Nature Biomedical Engineering https://doi.org/10.1038/s41551-020-00675-9, published online 8 February 2021.

This Article was originally published online incorrectly without open access, whereas it is actually covered by an Open Access licence (CC BY 4.0). The copyright line in the PDF mistakenly read “ $\odot$ The Author(s), under an exclusive licence to Springer Nature Limited 2021" but should have been '(C) The Author(s) 2021'.

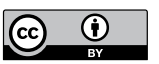

Open Access This article is licensed under a Creative Commons Attribution 4.0 International License, which permits use, sharing, adaptation, distribution and reproduction in any medium or format, as long as you give appropriate credit to the original author(s) and the source, provide a link to the Creative Commons license, and indicate if changes were made. The images or other third party material in this article are included in the article's Creative Commons license, unless indicated otherwise in a credit line to the material. If material is not included in the article's Creative Commons license and your intended use is not permitted by statutory regulation or exceeds the permitted use, you will need to obtain permission directly from the copyright holder. To view a copy of this license, visit http://creativecommons.org/licenses/ by/4.0/.

Published online: 7 May 2021

https://doi.org/10.1038/s41551-021-00741-w

(C) The Author(s) 2021 